Egyptian J. Anim. Prod. (2012) 49(1):87-93

\title{
SOME PHYSIOLOGICAL AND IMMUNOLOGICAL EFFECTS OF PHENYLLACTIC ACID IN BROILER CHICKS
}

\author{
A.A. Askar \\ Poultry Department, Faculty of Agriculture, Zagazig University, Zagazig, Egypt

\section{SUMMARY}

Some blood haemato-biochemical and immunological traits of broiler chicks have been investigated under the effect of phenyllactic acid (PA) treatment. One hundred and fifty unsexed one-day-old Hubbard chicks (body weight of $47.9 \pm 0.8 \mathrm{~g}$ ) were randomly allotted into five treatment groups. Birds of first group served as control and fed control diet (basal diet), while other four groups were received basal diet plus L-3-phenyllactic acid in different levels, $0.075 \%$ (PA1); $0.150 \%$ (PA2); 0.225\% (PA3) or $0.300 \%$ (PA4). Blood serum contents of total protein, Albumin and Globulin were differed significantly $(p<0.05$ or 0.01$)$ due to PA treatment. Birds group that received $0.150 \%$ of PA was accompanied by the highest value of blood proteins. No differences either among the other groups of PA or with the control group were noticed in blood proteins content. Highly significantly differences were observed in blood contents of total lipids and cholesterol in response to phenyllactic acid treatment. In general, birds treated with 0.75, 0.150 or 0.225\% of PA had lower levels of cholesterol than those of other experimental groups including the control one. All PA treated groups had lower levels of total lipids than those of control one. Birds group that received $0.150 \%$ of PA recorded the lowest value of total lipids comparing with other experimental groups including the control one. Blood glucose levels were affected significantly $(P<0.001)$ by $P A$ treatment, since the significantly lowest value was recorded when birds supplemented by $0.75 \%$ PA, while the highest one was observed in birds of control group. Effects of PA treatment on transaminase enzymes of liver (AST and ALT) were significant $(P<0.01)$ only for ALT. Birds treated with 0.075, 0.225 or $0.300 \%$ of PA showed low levels of ALT enzyme versus those recorded by birds received $0.150 \%$ of PA or by those of control group. Red blood cells (RBCs) count, hemoglobin ( $\mathrm{Hb})$ and packed cell volume (PCV \%) percentage of blood were affected significantly $(P<0.01)$ due to $P A$ treatment. Birds received $0.300 \%$ PA showed significantly higher values of these traits than those of control group birds that had the lowest ones. Number of WBC's, lymphocyte number percentage and relative weights of bursa of Fabricius and spleen were increased significantly in response to $P A(P<0.05$ or 0.001$)$. The later traits of birds received 0.150, 0.225 or $0.300 \%$ of $P A$ had nearly similar values and higher than those of birds received 0.075 of PA or those of control group. Most of the present results indicated that the treatment by PA showed a valuable improvement in some blood haemato-biochemical and immunological traits of broiler chicks, especially in birds received $0.150 \%$ of $P A$.

Key words: Phenyllactic acid, blood picture, blood components, immunological traits, broiler chicks.

\section{INTRODUCTION}

A potential health hazard for humans may occurs due to using antibiotics in birds to enhance their biological performance through the development of antibiotic-resistant pathogens that can be transferred to humans (Kelley et al., 1998) and consuming antibiotics residues that may be present in bird products (Dipeolu et al., 2005). The inclusion of antibiotics in the diets of livestock has been prohibited in the European Union since January 2006. Researchers attempted other alternatives claiming to enhance the biological performance of broiler chicken. Organic acids and their salts are generally regarded as safe and have been approved by most member states of EU to be used as stimulators for the biological performance of animals (Sheikh Adil et al., 2010).

Recently, Acidifiers as potential alternatives to antibiotics were used in the poultry industry to enhance the biological performance and reducing disease. Organic acids can play this role due to their antimicrobial activity, which reduces microbial competition with the host for nutrients and endogenous nitrogen losses, and by lowering the incidence of subclinical infections and the secretion of immune mediators (Dibner and Buttin, 2002, La Ragione and Woodward, 2003 and Denli et al., 2003). Organic acids in nondissociated (nonionised, more lipophilic) form can penetrate the bacteria cell wall and disrupt the normal physiology of certain types of microorganisms (Dhawale, 2005). Also, they reduce the $\mathrm{pH}$ of digesta, increase the pancreatic secretion and have trophic effects on mucosa layer of gastro-intestinal tract (Dibner and Buttin, 2002). Acidification with various organic acids has been reported to reduce the toxic components production by pathogens population, thus preventing the damage in epithelial cells of intestinal wall (Langhout, 2000), also improve the digestibility of proteins, calcium, phosphorus, magnesium, and zinc, and serve as substrates in 
the intermediary metabolism (Kirchgessner and Roth, 1988). These beneificial effects in turn improve the immune status and the physiological conditions of animal and poultry.

Phenyllactic acid (PA) is an organic acid that is produced as a by-product of phenylalanine metabolism (Thierry and Maillard, 2002). PA has recently been identified in cultures of Lactobacillus plantarum, and it is known to inhibit the growth of a wide variety of fungal strains (Ström et al., 2002 and Lavermicocca et $a l ., 2003$ ) and pathogenic bacteria (Dieuleveux et al., 1998). In addition, PA had less odor comparing with other organic acids, such as acetic acid. However, few studies have been conducted to evaluate the physiological and immunity effects of PA in broiler chicks. Therefore, this study was conducted to evaluate the physiological and immunity effects of using PA to enhance the biological performance of broiler chicks.

\section{MATERIALS AND METHODS}

One hundred and fifty unsexed one-day-old Hubbard chicks (body weight of 47.9 $\pm 0.8 \mathrm{~g}$ ) were randomly allotted into five treatment groups of 30 chicks each (three replicates/group of 10 chicks). Birds were treated by L-3-phenyllactic acid (PA) in powder form, which imported from Oxford Co., India by Al-Rahma office, Zagzig, Egypt. The PA was prepared by Qualikems Fine Chemicals Pvt. Ltd. Company (New Delhi, India). Birds of first group served as control and fed control diet (basal diet), while other four groups were received basal diet plus PA in different levels, $0.075 \%$ (PA1); $0.150 \%$ (PA2); $0.225 \%$ (PA3) or $0.300 \%$ (PA4). Tow basal diets (starter and finisher) were formulated to cover the nutrients requirements of broiler chicks reported by NRC (1994) during the experimental period in two phases (starter and finisher), starter one from 0-21 days and finisher one from 22-49 days. The ingredients and chemical composition of the two basal diets are shown in Table 1. All birds of this trial were kept under similar conditions of management during whole period of the experiment (49 days). Chicks were provided with $8 \%$ sugar solution for the first 12 hours. Vitamins and electrolytes were added to the drinking water for the first three days to avoid stress of transportation. Temperature inside the house of chicks was controlled and gradually reduced from $32^{\circ} \mathrm{C}$ to $20^{\circ} \mathrm{C}$ on day 49 . The chicks were maintained on a 24-hour consistent lighting schedule. A fresh feed and water were provided daily ad-libitum.

At the end of the experimental period (7weeks of age), five birds from each treatment group were randomly taken for slaughtering and collecting blood samples. Blood received from each bird was collected in two tubes (heparinized or non-heparinized tubes). The heparinized samples were used in determination the hematological parameters: red blood cells (RBC's) and white blood cells (WBC's) counts; hemoglobin content $(\mathrm{Hb})$ and packed cell volume percentage (PCV\%) according to Winterobe (1967). Two drops of blood from each sample were smeared on two glass slides and stained using May-Grunwald, Giemsa stains. One hundred of leukocytes cell including lymphocytes were counted on each slide to calculate lymphocyte percentage by dividing the number of lymphocytes by that of the whole leukocytes. The non-heparinized ones were centrifuged at $4000 \mathrm{rpm}$ for 15 minutes. Serum was separated and stored in deep freezer at $-20 \mathrm{C}^{\circ}$ for chemical analysis. Total protein; albumin; alanine transaminase, ALT and aspartate transaminase, AST activities; total lipids; cholesterol; and glucose were estimated using commercial kits purchased from Diamond Diagnostics Company, Egypt.

Data collected from this study were statistically analyzed using one way ANOVA through the GLM procedures of SPSS program (1993) as the following model: Yij $=\mu+\mathrm{Pi}+$ eij Where,

Yij = the observation on the ijth blood sample;

$\mu=$ general mean;

$\mathrm{Pi}=$ fixed effect of ith phenyllactic acid levels = $1 ; \ldots . . . ; 5$ (0.000; 0.075; $0.150 ; 0.225 ; 0.300 \%)$ and

eij = error of the model.

Multiple range tests were used to determine significance of differences in all studied traits according to Duncan (1955).

\section{RESULTS AND DISCUSSION}

As shown in Table 2, blood serum contents of total protein, Albumin and Globulin were differed significantly $(\mathrm{p}<0.05$ or 0.01$)$ due to PA treatment, whereas birds group that received $0.150 \%$ of PA was accompanied by the highest value of blood proteins. No differences either among the other groups of PA or with the control group were noticed in blood proteins content. The present results are in partially agreement with those obtained in laying hens by Wang et al. (2009a). They found that total protein, and albumin concentrations were higher in birds treated with $0.1 \%$ PA and those of control treatment group $(\mathrm{P}<0.05)$ than those received $0.3 \%$ PA. However, PA treatment in pigs had no effect on $\mathrm{IgG}$, and total protein concentration (Wang et al., 2009b).

Highly significantly differences were observed in blood contents of total lipids and cholesterol in response to phenyllactic acid treatment (Table 2). In general, birds treated with $0.75,0.150$ or $0.225 \%$ of PA had lower levels of cholesterol than those of other experimental groups including the control one. All PA treated groups had lower levels of total lipids than those 
of control one. Birds group that received $0.150 \%$ of PA recorded the lowest value of total lipids comparing with other experimental groups including the control one. However, no comparisons with other studies could be made because there have been no other studies conducted to evaluate the effects of PA on the blood glucose, Sheikh Adil et al. (2010) observed that blood contents of cholesterol didn't differ significantly due to the treatment by some organic acids in broiler chicks.

Levels of blood glucose were affected significantly $(\mathrm{P}<0.001)$ by $\mathrm{PA}$ treatment, since the highly ones were observed for birds of control groups and those treated with $0.225 \%$ of PA (157.8 and $157.0 \mathrm{mg} / \mathrm{dl}$, respectively) meanwhile, birds received $0.075 \%$ of PA had the significantly lowest level of blood glucose (125.2 $\mathrm{mg} / \mathrm{dl}$ ) as shown in Table 2. However, no comparisons with other studies could be made because there have been no other studies conducted to evaluate the effects of PA on the blood glucose, Sheikh Adil et al. (2010) observed that blood glucose didn't differ significantly due to the treatment by some organic acids in broiler chicks.

The effects of PA treatment on transaminase enzymes of liver (AST and ALT) were significant $(\mathrm{P}<0.01)$ only for ALT (Table 2). Birds treated with $0.075,0.225$ or $0.300 \%$ of PA showed low levels of ALT enzyme (45.2, 45.00 and $45.20 \mathrm{u} / \mathrm{l}$, respectively) versus those recorded by birds received $0.150 \%$ of PA or by those of control group (50.00 and $52.00 \mathrm{u} / \mathrm{l})$. Similar observations were reported also by Sheikh Adil et al. (2010) in broiler chicks, they found that AST and ALT of blood serum didn't differ significantly due to the treatment by some organic acids

Blood content of red blood cells (RBCs), hemoglobin $(\mathrm{Hb})$ and packed cell volume (PCV\%) percentage of blood were affected significantly $(\mathrm{P}<0.01)$ due to $\mathrm{PA}$ treatment. Birds received $0.300 \%$ PA showed significantly higher values of these traits $(2.66, \mathrm{x} 106 / \mathrm{mm} 3,7.22, \mathrm{~g} / \mathrm{dl}$ and $31.00 \%$, respectively) than those of control group birds that had the lowest ones. The available studies on PA effect on RBCs showed controversial results, Wang et al. (2009a) found in laying hens that red blood cell concentration was higher in birds dietary treated with $0.1 \%$ PA or those of control group $(\mathrm{P}<0.05)$ than in birds treated by 0.2 or $0.3 \%$ of PA, while Wang et al. (2009b) found that dietary treatment of PA had no effect on RBC in pigs.

The immunological status of broiler chicks was investigated under the effect of PA by determining WBC's number per $\mathrm{mm} 3$, the percentage of lymphocyte number of total number of WBC's and the relative weights of bursa of Fabricius and spleen presented in Table 4. The later four measurements were increased significantly in response to $\mathrm{PA}(\mathrm{P}<0.05$ or 0.001). In general, the immunological traits in birds received $0.150,0.225$ or $0.300 \%$ of PA had nearly similar values and higher than those of birds received 0.075 of PA or those of control group. These results are similar to some extent with those obtained by Wang et al. (2009a). They found that PA can partially improve the profile of blood characteristics, such as lymphocytes and WBC's in the short term, whereas WBC's count in laying hens was higher in birds dietary treated with $0.1 \%$ PA or those of control group $(\mathrm{P}<0.05)$ than in birds treated by 0.2 or $0.3 \%$ of PA. Also, Wang et al. (2010) found in broiler chicks that PA treatment $(0.1,0.2$ or $0.3 \%)$ led to an increase $(\mathrm{P}<0.05)$ in the concentrations of WBC's and lymphocyte percentage, while the relative weights of bursa of Fabricius and spleen were unaffected by any of the dietary supplementations. Wang et al. (2009b) found in pigs that lymphocyte percentage on $\mathrm{d} 42$ increased linearly as dietary PA increased $(\mathrm{P}<0.05)$. Additionally, WBC's counts on $\mathrm{d} 42$ tended to increase as PA levels increased $(\mathrm{P}<0.10)$. Reviewed and present findings suggested that PA, like other organic acids, could stimulate the immune system. Although organic acids effect on the immunological status has not been well documented, it has been clearly established that several organic acids can affect microorganisms population of gut intestine that are necessary for gut immune system development (Wang et al., 2009a\&b and Czerwiński et al., 2010). Also, the attained reduction in subclinical infections due to antimicrobial effects of organic acids can contribute in nutrient digestibility improvement beside the reduction in nutrients demand for immune tissues of gut. Reducing $\mathrm{pH}$ value of the diet due to organic acids may improve the utilization of minerals, such as $\mathrm{Ca}$, which have positive effects on the immunity ( Mroz et al., 2000), as well as, citric acid can help to release minerals bound to the phytate molecule, which in turn increase the utilization of $\mathrm{Ca}, \mathrm{P}$, and $\mathrm{Zn}$ (Kirchgessner and Roth, 1988; Boling et al., 2000 and Liem et al., 2008). Moreover, organic acids can improve the digestibility of proteins, $\mathrm{Ca}, \mathrm{P}, \mathrm{Mg}$, and $\mathrm{Zn}$, and serve as substrates in the intermediary metabolism (Sheikh Adil et al., 2010). These additional minerals may provide another explanation for the improved immune status indicators.

In conclusion, PA treatment could be exerting some positive effects on blood haematobiochemical traits and immune system. It may be beneficial to supplement the diets of broiler chicks with PA to improve and/or maintain it's physiological and immunity status. Most of blood profile traits, except immune status indicators, were not continually improved by PA levels. It is 
likely that there was no level of PA responses on the improvement of blood parameters.

\section{REFERENCES}

Boling, S.D., D.M. Webel, I. Mavromichalis, C.M. Parsons and D.H. Baker, 2000. The effects of citric acid on phytate-phosphorus utilization in young chicks and pigs. J. Anim.Sci.78: 682-689.

Czerwiński, J., O. Højberg, S. Smulikowska, R.M. Engberg and A. Mieczkowska, 2010. Influence of dietary peas and organic acids and probiotic supplementation on performance and caecal microbial ecology of broiler chickens. Br Poult Sci. 51: 258-69.

Denli, M., F. Okan and K. Celik, 2003. Effect of dietary probiotic, organic acid and antibiotic supplementation to diets on broiler performance and carcass yield. Pakistan Journal of Nutrition. 2: 89-91.

Dhawale, A., 2005. Better eggshell quality with a gut acidifier. Poultry International. 44: 18-21.

Dibner, J.J. and P. Buttin, 2002. Use of organic acids as a model to study the impact of gut microflora on nutrition and metabolism. Journal of Applied Poultry Research. 11: 453463.

Dieuleveux, V., D.P.D. Van, J. Chataud and M. Gueguen, 1998. Purification and characterization of anti-Listeria compounds produced by Geotrichum candidum. Appl. Environ. Microbiol. 64: 800-803.

Dipeolu, M.A., D. Eruvbetine, E.B. Oguntona, O.O. Bankole and K.S. Sowunmi, 2005. Comparison of effects of antibiotics and enzyme inclusion in diets of laying birds. Arch. Zootec. 54: 3-11.

Duncan, D.B., 1955. Multiple range and multiple F test. Biometric, 11: 1-42.

Kelley T.R., O.C. Pancorbo, W.C. Merka and H.M. Barnhart, 1998. Antibiotic resistance of bacterial litter isolates. Poult. Sci. 77: 243247.

Kirchgessner, Mq. and F.X. Roth, 1988. Ergotrope effekte durch organische sauren in der fekelaufzucht und schweinemast. Ubersichten zur Tiererenährung.16: 93-108.

La Ragione, R.M. and M.J. Woodward, 2003. Competitive exclusion by Bacillus subtilis spores of Salmonella enterica serotype Enteritidis and Clostridium perfringens in young chickens. Veterinary Microbiology. 94: 245-256.

Langhout, P., 2000. New additives for broiler chickens. Feed Mix. 24-27.
Lavermicocca, P., F.V. Valerio and A. Visconti, 2003. Antifungal activity of phenyllactic acid against molds isolated from bakery products. Appl. Environ. Microbiol. 69: 634-640.

Liem, A., G.M. Pesti and H.M.Jr. Edwards, 2008. The effect of several organic acids on phytate phosphorus hydrolysis in broiler chicks. Poult Sci. 87: 689-93.

Mroz, Z., A.W. Jongbloed, K.H. Partanen, K. Vreman, P.A. Kemme and J. Kogut, 2000. The effects of calcium benzoate in diets with or without organic acids on dietary buffering capacity, apparent digestibility, retention of nutrients, and manur characteristics in swine. J. Anim. Sci. 78: 2622-2632.

NRC, 1994. National Research Council. Nutrient Requirements of Poultry. 9th ed., National Academy of Science, Washington. D.C., USA.

Sheikh Adil, Tufail Banday, Gulam Ahmad Bhat, Masood Saleem Mir, and Manzoor Rehman, 2010. Effect of Dietary Supplementation of Organic Acids on Performance, Intestinal Histomorphology, and Serum Biochemistry of Broiler Chicken. Vet Med Int.; 479-485.

SPSS program, 1993. Statistical Package for Social Science, SPSS for Windows. Computer Program, version, 5-1.

Ström, K., J. Sjögren, A. Broberg and J. Schnürer, 2002. Lactobacillus plantarum MiLAB 393 produces the antifungal cyclic dipeptides cyclo (L-Phe-L-Pro) and cyclo (LPhe-trans-4-OH-L-Pro) and 3-phenyllactic acid. Appl. Environ. Microbiol. 68: 43224327.

Thierry, A., and M.B. Maillard, 2002. Production of cheese flavor compounds derived from amino acid catabolism by Propionibacterium freudenreichii. Lait 82: 17-32.

Wang, J.P., J.S. Yoo, J.H. Lee, T.X. Zhou, H.D. Jang, H.J. Kim and I.H. Kim, 2009a. Effects of phenyllactic acid on production performance, egg quality parameters, and blood characteristics in laying hens. J. Appl. Poult. Res., 18: 203-209. doi: 10. 3382 /japr. 2008-00071.

Wang, J.P., J.S. Yoo, J.H. Lee, H.D. Jang, H.J. Kim, S.O. Shin, S.I. Seong and I.H. Kim, 2009b. Effects of phenyllactic acid on growth performance, nutrient digestibility, microbial shedding, and blood profile in pigs. J. Anim. Sci., 87: 3235-3243. doi: 10. 2527/jas. 20081555 .

Winterobe, M.M., 1967. Clinical Hematology; 6th ed. London: Kimpton. 
Table 1. Composition and Calculated chemical analysis of the basal diet

\begin{tabular}{lcc} 
Ingredient & Starter (\%) & Finisher (\%) \\
\hline Ground yellow corn & 54.50 & 60.90 \\
Soybean meal 44\% & 32.00 & 26.00 \\
Corn gluten 60\% & 6.56 & 5.00 \\
Sun flower oil & 3.50 & 4.70 \\
Dicalcium phosphate & 1.65 & 1.60 \\
Limestone & 1.00 & 1.00 \\
Salt & 0.42 & 0.40 \\
Vit. Min. Premix* & 0.30 & 0.30 \\
DL-methionine & 0.07 & 0.10 \\
Total & $\mathbf{1 0 0 . 0}$ & $\mathbf{1 0 0 . 0}$ \\
Calculated analysis** & & \\
Crude protein & 22.94 & 19.90 \\
ME Kcal/kg & 3091 & 3219 \\
Calcium \% & 0.85 & 0.82 \\
Av. Phosphors \% & 0.46 & 0.44 \\
\hline *Supplied per kg of the diet: Vit. A 2000 IU; Vit. D3 2200 IU; Vit. E 10 mg; Vit. K3 2 mg; Vit. B1 1 mg, Vit. B2 \\
5 mg, Vit. B6 1.5 mg; Vit. B12 0.01 mg; Niacin 30 mg; Folic acid 1 mg; Biotin 0.05 mg; Choline chloride 300 mg; \\
Copper 10 mg; Iron 30 mg; Manganese 60 mg; Zinc 50 mg; Iodine 1 mg; Selenium 0.1 mg; cobalt 0.1 mg. \\
**Calculated according to NRC (1994).
\end{tabular}

Table 2. Means ( $X)$ and standard errors (SE) of some blood serum components in broiler chicks as affected by phenylactic acid.

\section{Traits}

\begin{tabular}{|c|c|c|c|c|c|c|c|c|c|c|}
\hline \multicolumn{2}{|c|}{ Items } & & \multirow{2}{*}{$\begin{array}{c}\begin{array}{c}\text { Total } \\
\text { protein } \\
\text { (g/dl) }\end{array} \\
* *\end{array}$} & \multirow{2}{*}{$\begin{array}{l}\begin{array}{l}\text { Albumin } \\
\text { (g/dl) }\end{array} \\
\qquad\end{array}$} & \multirow{2}{*}{$\begin{array}{c}\begin{array}{c}\text { Globulin } \\
\text { (g/dl) }\end{array} \\
* *\end{array}$} & \multirow{2}{*}{$\begin{array}{c}\text { Total } \\
\text { lipids } \\
\text { (g/l) } \\
* *\end{array}$} & \multirow{2}{*}{$\begin{array}{c}\begin{array}{c}\text { Cholesterol } \\
\text { (mg/dl) }\end{array} \\
* *\end{array}$} & \multirow{2}{*}{$\begin{array}{c}\begin{array}{c}\text { Glucose } \\
\text { (mg/dl) }\end{array} \\
* *\end{array}$} & \multirow{2}{*}{$\begin{array}{c}\text { AST } \\
(\mathbf{u} / \mathbf{l}) \\
\mathrm{Ns}\end{array}$} & \multirow{2}{*}{$\begin{array}{r}\begin{array}{c}\text { ALT } \\
(\mathbf{u} / \mathbf{l})\end{array} \\
* *\end{array}$} \\
\hline & & & & & & & & & & \\
\hline \multirow{10}{*}{ 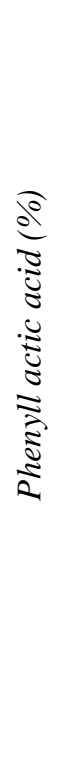 } & \multirow{2}{*}{$\begin{array}{l}8 \\
\varrho \\
\varrho\end{array}$} & $x$ & $4.90^{b}$ & $1.80^{b}$ & $3.10^{b}$ & $6.03^{a}$ & $143.0^{\mathrm{a}}$ & $157.8^{a}$ & 32.50 & $50.00^{\mathrm{a}}$ \\
\hline & & $\frac{\omega}{\sim}$ & 0.11 & 0.07 & 0.06 & 0.038 & 1.10 & 1.24 & 0.38 & 1.10 \\
\hline & \multirow{2}{*}{$\stackrel{n}{\circ}$} & $x$ & $4.80^{b}$ & $1.84^{b}$ & $2.96^{b}$ & $5.78^{b}$ & $131.8^{b}$ & $125.2^{\mathrm{b}}$ & 32.66 & $45.20^{\mathrm{b}}$ \\
\hline & & $\frac{\pi}{2}$ & 0.11 & 0.07 & 0.06 & 0.034 & 1.20 & 0.97 & 0.59 & 0.97 \\
\hline & \multirow{2}{*}{$\frac{\circ}{\stackrel{n}{0}}$} & $x$ & $5.92^{\mathrm{a}}$ & $2.10^{\mathrm{a}}$ & $3.82^{\mathrm{a}}$ & $4.56^{\mathrm{e}}$ & $120.2^{b}$ & $155.8^{\mathrm{a}}$ & 32.68 & $52.00^{\mathrm{a}}$ \\
\hline & & $\sqrt[n]{\Omega}$ & 0.19 & 0.07 & 0.15 & 0.031 & 1.50 & 1.02 & 0.39 & 1.00 \\
\hline & \multirow{2}{*}{$\underset{\approx}{\tilde{0}}$} & $x$ & $4.80^{b}$ & $1.78^{b}$ & $3.02^{b}$ & $5.33^{\mathrm{d}}$ & $120.2^{b}$ & $157.0^{\mathrm{a}}$ & 31.16 & $45.00^{\mathrm{b}}$ \\
\hline & & $\frac{\pi}{\Omega}$ & 0.14 & 0.07 & 0.11 & 0.026 & 1.50 & 1.64 & 0.83 & 0.84 \\
\hline & \multirow{2}{*}{ 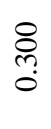 } & $x$ & $5.00^{b}$ & $1.84^{\mathrm{b}}$ & $3.16^{b}$ & $5.58^{c}$ & $143.3^{\mathrm{a}}$ & $155.8^{\mathrm{a}}$ & 31.82 & $45.20^{\mathrm{b}}$ \\
\hline & & $\frac{\pi}{\sim}$ & 0.12 & 0.06 & 0.07 & 0.032 & 2.62 & 1.02 & 0.42 & 0.80 \\
\hline
\end{tabular}

$*=$ significant $(\mathrm{P}<0.05)^{* *}=$ highly significant $(\mathrm{P}<0.01)$ and $\mathrm{ns}=$ not significant

Means in the same column bearing the same superscripts did not differ from each other; otherwise they differ $(\mathrm{P} \leq 0.05$ or 0.01$)$. 
Table 3. Means $(\bar{X})$ of blood picture traits in broiler chicks as affected by phenyllactic acid

\begin{tabular}{|c|c|c|c|c|c|}
\hline \multirow{2}{*}{\multicolumn{2}{|c|}{ Items }} & & \multicolumn{3}{|c|}{ Traits } \\
\hline & & & RBC's $\left(x 10^{6}\right) / \mathrm{mm}^{3}$ & $\mathrm{Hb}(\mathrm{g} / \mathrm{dl})$ & PCV (\%) \\
\hline \multirow{11}{*}{ 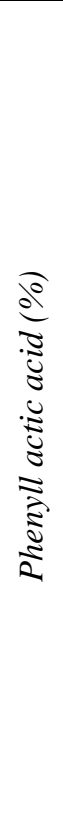 } & \multirow{3}{*}{ : } & & $* *$ & $* *$ & $* *$ \\
\hline & & $x$ & $2.20^{\mathrm{b}}$ & $6.10^{\mathrm{b}}$ & $26.00^{c}$ \\
\hline & & 窝 & 0.08 & 0.16 & 1.14 \\
\hline & \multirow{2}{*}{$\begin{array}{l}n \\
\vdots \\
0 \\
0\end{array}$} & $x$ & $2.60^{\mathrm{a}}$ & $7.08^{\mathrm{a}}$ & $29.20^{\mathrm{ab}}$ \\
\hline & & 乩 & 0.12 & 0.12 & 0.73 \\
\hline & \multirow{2}{*}{$\frac{n}{0}$} & $x$ & $2.50^{\mathrm{a}}$ & $6.86^{\mathrm{a}}$ & $28.00^{\mathrm{bc}}$ \\
\hline & & 仯 & 0.06 & 0.08 & 0.45 \\
\hline & \multirow{2}{*}{ 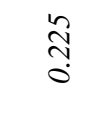 } & $x$ & $2.65^{\mathrm{a}}$ & $7.00^{\mathrm{a}}$ & $30.80^{\mathrm{a}}$ \\
\hline & & 跑 & 0.06 & 0.16 & 0.86 \\
\hline & \multirow{2}{*}{ 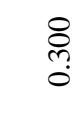 } & $x$ & $2.66^{\mathrm{a}}$ & $7.22^{\mathrm{a}}$ & $31.00^{\mathrm{a}}$ \\
\hline & & $\sqrt[w]{2}$ & 0.04 & 0.10 & 0.89 \\
\hline
\end{tabular}

$* *$ = highly significant $(\mathrm{P}<0.01)$.

Means in the same column bearing the same superscripts did not differ from each other; otherwise they differ $(\mathrm{P} \leq 0.001)$.

Table 4. Means $(X)$ and standard errors (SE) of some immunological traits in broiler chicks as affected by phenylactic acid.

\begin{tabular}{|c|c|c|c|c|c|c|}
\hline \multirow{2}{*}{\multicolumn{2}{|c|}{ Items }} & & \multicolumn{3}{|c|}{ Traits } & \multirow[b]{2}{*}{ Spleen $^{2}(\%)$} \\
\hline & & & WBC's $\left(x 10^{3}\right) / \mathrm{mm}^{3}$ & Lymphocyte $^{1}(\%)$ & Bursa of Fabricius ${ }^{2}(\%)$ & \\
\hline \multirow{11}{*}{ 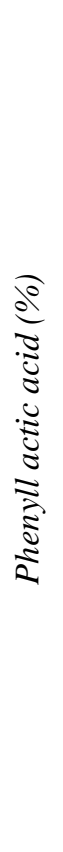 } & \multirow{3}{*}{\begin{tabular}{l}
8 \\
\hdashline \\
0
\end{tabular}} & & $* *$ & $*$ & $*$ & $* *$ \\
\hline & & $\rtimes$ & $19.2^{\mathrm{c}}$ & $69.40^{\mathrm{b}}$ & $0.188^{b}$ & $0.123^{\mathrm{d}}$ \\
\hline & & 空 & 1.06 & 0.72 & 0.059 & 0.068 \\
\hline & \multirow{2}{*}{$\stackrel{n}{0}$} & $\rtimes$ & $35.2^{\mathrm{b}}$ & $70.54^{\mathrm{ab}}$ & $0.199^{\mathrm{ab}}$ & $0.135^{\mathrm{cd}}$ \\
\hline & & 空 & 1.59 & 0.67 & 0.062 & 0.066 \\
\hline & \multirow{2}{*}{$\begin{array}{l}\frac{n}{n} \\
0\end{array}$} & $x$ & $43.8^{\mathrm{a}}$ & $71.48^{a b}$ & 0.215 & $0.143^{b c}$ \\
\hline & & 空 & 1.02 & 0.60 & $0.086^{\mathrm{a}}$ & 0.059 \\
\hline & \multirow{2}{*}{ 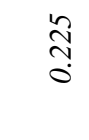 } & $x$ & $40.2^{\mathrm{a}}$ & $72.60^{\mathrm{a}}$ & 0.219 & $0.160^{b}$ \\
\hline & & $\sqrt[\underline{w}]{2}$ & 1.36 & 0.73 & $0.059^{\mathrm{a}}$ & 0.057 \\
\hline & \multirow{2}{*}{$\begin{array}{l}8 \\
\text { ֻ. } \\
0\end{array}$} & $x$ & $42.0^{\mathrm{a}}$ & $71.28^{\mathrm{ab}}$ & $0.201^{\mathrm{ab}}$ & $0.178^{\mathrm{a}}$ \\
\hline & & 至 & 1.41 & 0.77 & 0.078 & 0.055 \\
\hline
\end{tabular}

$*$ = significant $(\mathrm{P}<0.05)$ and $* *=$ highly significant $(\mathrm{P}<0.01)$.

Means in the same column bearing the same superscripts did not differ from each other; otherwise they differ $(\mathrm{P} \leq 0.05$ or 0.001$)$.

${ }^{1}$ Values presented as a percentage of total white blood cells count.

${ }^{2}$ Values presented as a percentage of body weight. 


\section{بعض التأثيرات الفسيولجية والمناعية لحامض الفنيل أسيتك أسيد في بداري اللحم}

علي عبدالرازق سيد أحمد عسكر

\section{قسم الدواجن، كلية الزراعة، جامعة الزقازيق، الزقازيق}

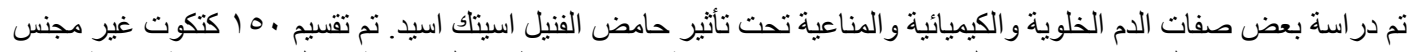

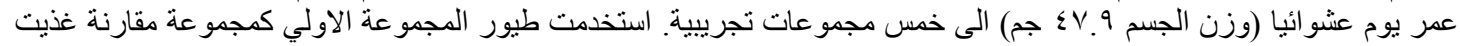

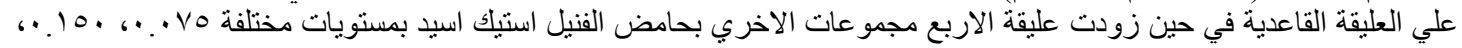

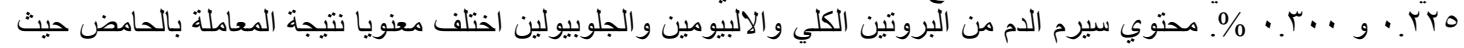

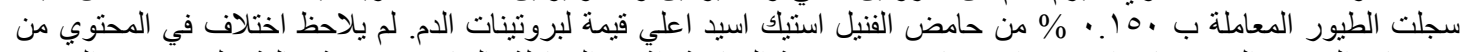

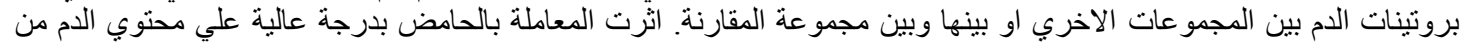

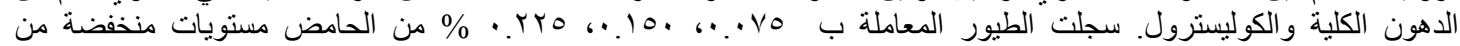

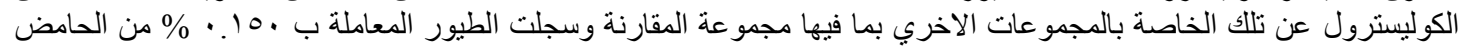

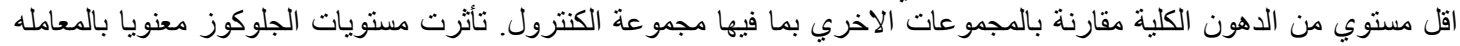

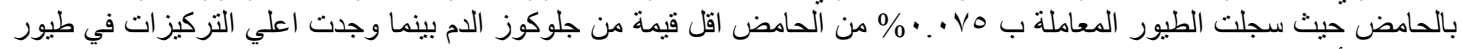

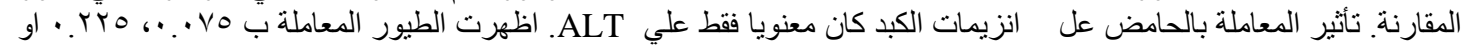

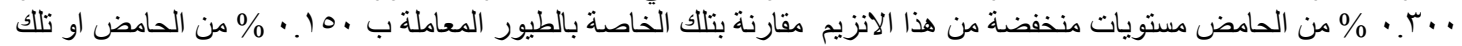

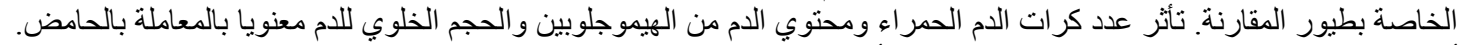

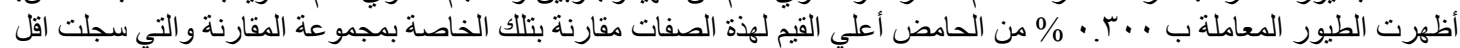

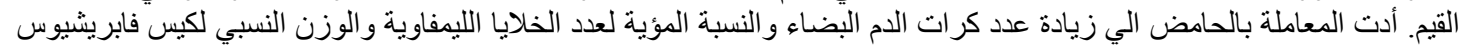

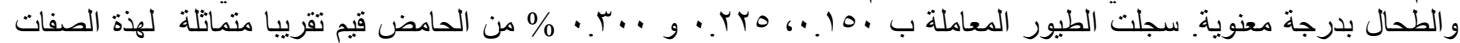

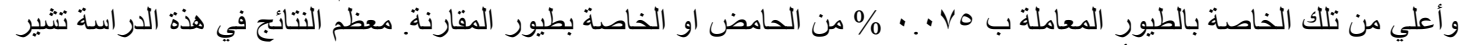

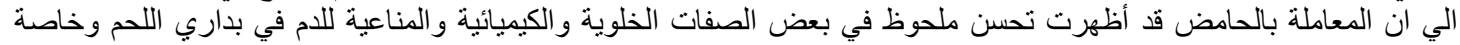

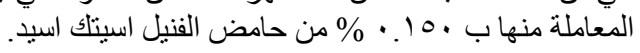

